\title{
Qaly - ocena efektywności klinicznej z użyciem kwestionariusza EQ-5D-3L
}

\author{
Qaly - measuring clinical effectiveness \\ using EQ-5D-3L questionnaire
}

\author{
Agata Karolina Pietrzak ${ }^{1}$, Karolina Kucnerowicz², Witold Cholewiński³ \\ Piotr Martenka ${ }^{4}$,Erwin Strzesak ${ }^{2}$ \\ ${ }^{1}$ Zakład Medycyny Nuklearnej, Wielkopolskie Centrum Onkologii, Poznań, Polska \\ ${ }^{2}$ Dział Ewidencji Świadczeń Medycznych Wielkopolskiego Centrum Onkologii \\ ${ }^{3}$ Katedra i Zakład Elektroradiologii Uniwersytetu Medycznego im. K.Marcinkowskiego w Poznaniu \\ ${ }^{4}$ Zakład Radioterapii Wielkopolskiego Centrum Onkologii
}

\section{Wstęp}

Zgodnie z definicją Światowej Organizacji Zdrowia (ang. World Health Organization; WHO), przez pojęcie zdrowia rozumieć należy zbiór czynników, wpływających na samoocenę człowieka w odniesieniu do otoczenia, w którym żyje. Poczucie zdrowia oznacza zatem psychiczną i fizyczną zdolność do samodzielnej egzystencji i pełnienia ról społecznych, wspólnie decydujących o jakości życia jednostki (ang. quality of life; QoL, QOL) $[1,2]$.

Pierwszą międzynarodową sekcję badającą QoL powołano w 1994r. w strukturze WHO. Prace zespołu poświęcono analizie wielu aspektów QoL, w szczególności - QoL związanej ze stanem zdrowia (ang. healthrelated QoL; HRQoL). Badanie HRQoL opiera się na standaryzowanej ankietyzacji z użyciem różnego typu kwestionariuszy, których treść stanowi zbiór danych, służących analizie czynników wpływających na samoocenę zdrowotną chorego. Najczęściej stosowanym formularzem, rekomendowanym przez Narodowy Instytut Doskonalenia Zdrowia i Opieki (ang. National Institute for Health and Care Excellence; NICE, Wielka Brytania) jest model, opracowany przez fundację EuroQoL (Rotterdam, Holandia, powołana w 1987r.). Działalność EuroQoL koncentruje się wokół jakości życia społeczeństw krajów Europy. Kwestionariusz EuroQoL służy ocenie poziomu HRQoL według schematu: 5 obszarów - 3 poziomy (ang. EuroQoL 5 dimensions - 3 levels; EQ-5D-3L) [3,4]. Oznacza to, że struktura formularza obejmuje pięć pytań, uwzględniając trzy możliwe odpowiedzi. Poszczególne warianty odpowiedzi pozwalają choremu dokonać

Adres do korespondencji

Agata Karolina Pietrzak

Zakład Medycyny Nuklearnej,

Wielkopolskie Centrum Onkologii, ul. Garbary 15, 61-866 Poznań, Polska

Telefon. $+48618850-789$

e-mail: agata.pietrzakk@gmail.com 
samooceny stopnia sprawności w wybranym obszarze [3,4]. Każdemu z wariantów, zgodnie z opracowanymi przez EuroQoL standardami, przyporządkowana jest określona punktacja w zakresie o-10o punktów. 100 punktów oznacza zwykle rok życia w pełnym zdrowiu po zakończonym leczeniu lub poczucie pełnego komfortu zdrowotnego w danym okresie. Badaniu standaryzowanemu towarzyszy dodatkowo samoocena chorego z wykorzystaniem - wyrażonej procentowo - skali wizualnej (ang. EuroQoL visual analogue scale; EQ-VAS), za pomocą której chory dokonuje subiektywnej, niestandaryzowanej oceny poziomu HRQoL [5].

Dane zgromadzone w wyniku badań z użyciem kwestionariusza EQ-5D-3L pozwalają oszacować efektywność kliniczną postępowania medycznego, zastosowanego wobec chorego onkologicznie. Jednakże skali użytej w formularzu EQ-5D-3L przyporządkować można także określoną wartość pieniężną, którą ustanawia odpowiedni urząd (w Polsce - Główny Urząd Statystyczny; GUS). Kwota odpowiadająca wartości 100 punktów HRQoL (ang. EuroQoL Index; EQ Index) jest zmienna i zależy od wartości krajowego produktu brutto, przypadającego na jednego obywatela danego kraju. Zestawienie wartości EQ Index i EQ VAS z całkowitym zyskiem wynikającym z życia w zdrowiu, określane jest mianem wskaźnika Qaly. Współczynnik Qaly jest zatem wielkością wskazującą całkowity zysk zdrowotny, wynikający z wdrożonego postępowania wobec chorego onkologicznie, obejmującego diagnostykę, terapię, rekonwalescencję, a także zdolność badanej osoby do pełnienia wybranej roli społecznej i powrotu do aktywności zawodowej.

\section{Cel pracy}

Celem niniejszej pracy jest charakterystyka wskaźnika Qaly w kontekście oceny efektywności klinicznej postępowania diagnostycznego i terapeutycznego wobec chorych onkologicznie w oparciu o dostępne piśmiennictwo naukowe.

\section{Materiał i metoda}

Treść niniejszej pracy powstała w oparciu o dostępne piśmiennictwo naukowe, związane z badaniami HRQoL, opublikowane w latach 2012-2018. Prezentowane dane pochodzą z zasobów National Center for Biotechnology Information (NCBI; Stany Zjednoczone Ameryki, 8600 Rockville Pike, Bethesda MD, 20894 USA, zrzeszająca Medline, PubMed, PubMed Central i wiele innych baz naukowych). Autorzy niniejszego manuskryptu użyli narzędzi zaawansowanego wyszukiwania $\mathrm{z}$ wykorzystaniem następujących słów kluczowych: jakość życia, onkologia, Qaly, EQ-5D-3L. Użyte w treści pracy polskojęzyczne opracowania, pochodzą spoza ww. baz naukowych.

\section{Omówienie}

\section{Struktura kwestionariusza EQ-5D-3L}

Celem badania metodą formularza EQ-5D-3L jest, zasadniczo, ocena HRQoL w kontekście zdolności lokomotorycznych (ang. mobility), możliwości m.in. samodzielnego realizowania czynności higienicznych (ang. self-care), wykonywania codziennych obowiązków i aktywności (ang. usual activities). Poziomy 4. i 5. pozwalają natomiast rozróżnić poczucie dyskomfortu i bólu (ang. discomfort and pain ratio), a także lęku i depresji (ang. anxiety and depression ratio), wywołanych rozwojem choroby lub będących działaniem niepożądanym terapii przeciwnowotworowej $[3,4]$.

Kwestionariusz EQ-5D-3L przyporządkowuje każdemu z 5. pytań 3 możliwe warianty odpowiedzi. Każdej możliwości przyporządkowano określoną punktację, zgodnie z którą 20 punktów oznacza maksymalną samodzielność w badanym obszarze, 10 - ograniczoną zdolność do wykonywania czynności lub konieczność korzystania z pomocy osób trzecich, a o - całkowitą niesamodzielność lub najwyższe natężenie mierzonej cechy, np. nieustanny ból lub niepokój (Tabela 1.) [6]. Przeprowadzenie badania z użyciem kwestionariusza powinno odbywać się w osobnym, przeznaczonym do tego celu pomieszczeniu, zapewniając choremu intymność. Przed rozpoczęciem badania, chory powinien zostać poinformowany o strukturze, celu 
i znaczeniu ankietyzacji. W razie konieczności, asystent (np. pracownik wydzielonej sekcji, sekretariatu, wskazanego biura) powinien służyć osobie badanej pomocą w odczytywaniu i zakreślaniu odpowiedzi.

Tabela 1. Kwestionariusz EQ-5D-3L (w oparciu o źródło: EuroQol Research Foundation) [6]

Struktura kwestionariusza EQ-5D-3L

\begin{tabular}{ccc}
\hline Badana cecha & Warianty oceny & Punktacja \\
\hline \multirow{2}{*}{ Zdolności } & Nie mam żadnych problemów & 20 \\
lokomotoryczne & Miewam problem z poruszaniem się & 10 \\
& Jestem osobą leżącą & 0 \\
\hline \multirow{3}{*}{ Samodzielność } & Nie mam żadnych problemów & 20 \\
& Miewam problem z myciem lub ubieraniem się & 10 \\
& Nie umyję się i nie ubiorę samodzielnie & 0 \\
\hline \multirow{3}{*}{ Codzienne czynności } & Nie mam żadnych problemów & 20 \\
& Miewam problem z codziennymi aktywnościami & 10 \\
& Nie mogę wykonywać codziennych czynności & 0 \\
\hline \multirow{3}{*}{ Dyskomfort a ból } & Nie mam żadnych problemów & 20 \\
& Czasami odczuwam dyskomfort lub ból & 10 \\
& Stale odczuwam dyskomfort lub ból & 0 \\
\hline \multirow{2}{*}{ Niepokój a lęk } & Nie mam żadnych problemów & 20 \\
& Zdarza mi się odczuwać niepokój lub lęk & 10 \\
& Stale odczuwam niepokój lub lęk & 0 \\
\hline
\end{tabular}

Wskaźnik Qaly, czyli całkowity zysk zdrowotny

Badanie wybranym kwestionariuszem HRQoL można przeprowadzić na dowolnym etapie leczenia, a także w okresie rekonwalescencji chorego onkologicznie. Szczególnie wartościowa wydaje się być analiza prowadzona po upływie pełnego roku po zakończonym leczeniu. Działanie takie pozwala na obliczenie wskaźnika Qaly, czyli ocenę całkowitego zysku zdrowotnego, inaczej: efektywności klinicznej i kosztowej postępowania medycznego. Wyliczenia wskaźnika Qaly dokonuje się w oparciu o obwieszczenie Prezesa Głównego Urzędu Statystycznego z dnia 29.10.2019 r. w sprawie szacunków wartości produktu krajowego brutto na jednego mieszkańca $w$ latach 2015-2017. Zgodnie z powyższa regulacją, wartość Qaly stanowi trzykrotność wysokości produktu krajowego brutto, przypadającego na jednego mieszkańca Polski $w$ latach 2015-2017. Stąd, wysokość progu kosztu uzyskania dodatkowego roku życia skorygowanego o jakość wynosi 147024 zł (3 x 49008 zł) [7]. Zgodnie z §5 ust. 2. pkt 4. rozporzadzenia Ministra Zdrowia $z$ dnia 02.04.2012r. $w$ sprawie minimalnych wymagań, jakie musza spetniać analizy uwzględnione we wnioskach o objęcie refundacją $i$ ustalenie urzędowej ceny zbytu oraz o podwyższenie urzędowej ceny zbytu leku, środka spożywczego specjalnego przeznaczenia żywieniowego, wyrobu medycznego, które nie maja odpowiednika refundowanego w danym wskazaniu (Dz. U. z 2012 r., poz. 388) [8], wskazana kwota powinna stanowić punkt odniesienia dla oszacowania kosztu uzyskania dodatkowego roku życia skorygowanego o jakość życia w analizach ekonomicznych. W myśl powyższych regulacji prawnych, 100 punktów uzyskanych metodą badania stosownym kwestionariuszem, oznacza całkowity zysk zdrowotny, wyrażony kwota 147 o24zt.

\section{Qaly w Polsce i na świecie}

Do najczęściej występujących nowotworów złośliwych w Europie Środkowej, a zatem i w Polsce, zaliczamy: rak sutka, płuca, jelita grubego i stercza (Rycina 1.), będące głównym obszarem zainteresowania badaczy HRQoL. Jednakże, bez względu na etiologię i częstość występowania poszczególnych typów chorób 
onkologicznych, wdrożenie wybranego postępowania terapeutycznego obarczone jest ryzykiem wystąpienia działań niepożądanych, obniżających HRQoL chorych. Analiza poziomu HRQoL, uwzględniająca wskaźnik Qaly, pozwala na precyzyjną ocenę efektywności klinicznej wybranego postępowania i to, jak zastosowany protokół leczniczy wpływa na dalsze życie chorego.

\section{Częstość występowania nowotworów złośliwych w Polsce}

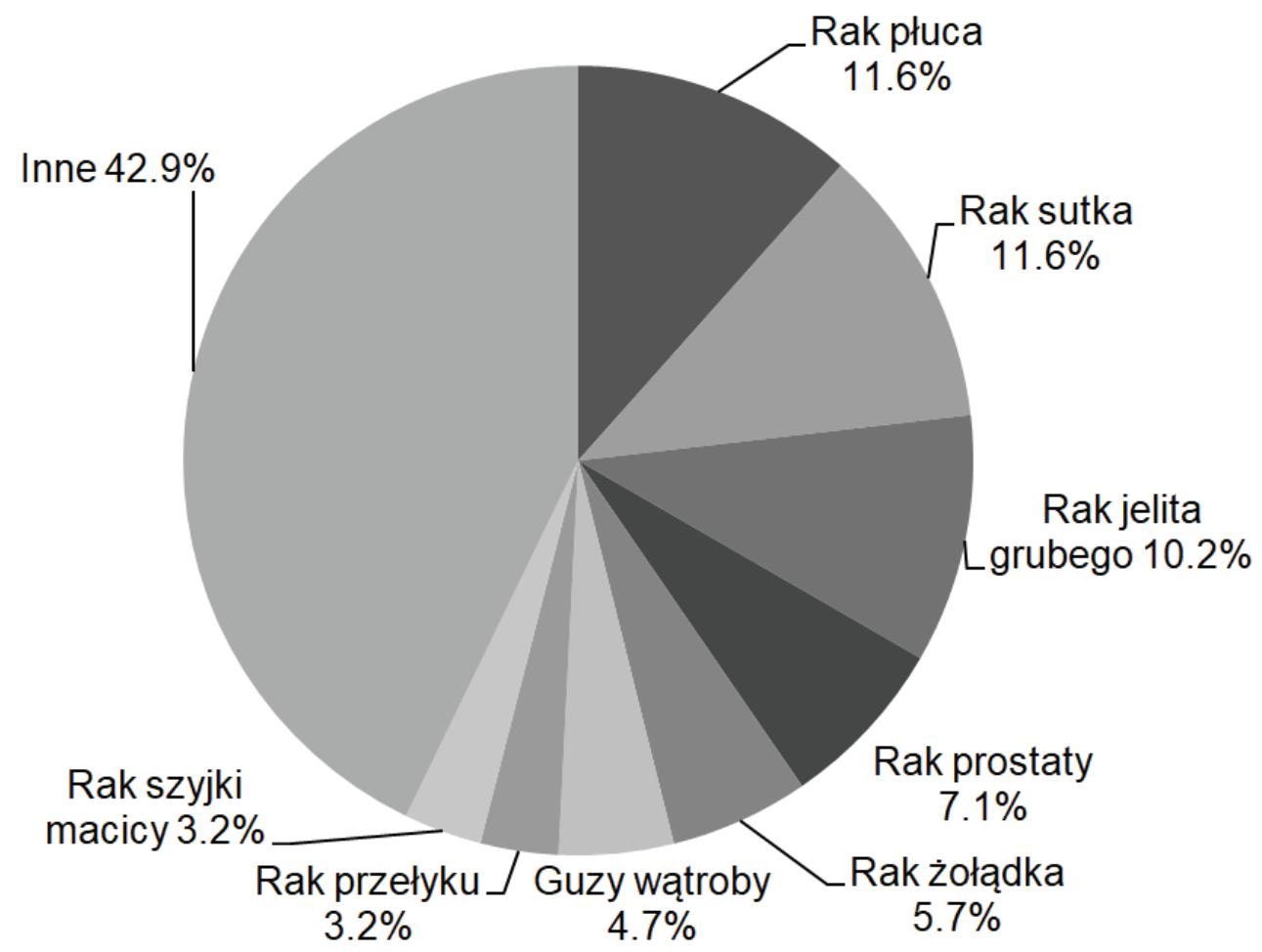

Rycina 1. Udział procentowy poszczególnych grup nowotworów złośliwych w całkowitej liczbie chorób onkologicznych w Europie Środkowej (źródło: Globocan 2018) [9]

Badania wartości wskaźnika Qaly prowadzone są w ramach standardowej praktyki przez wiodące ośrodki onkologiczne na świecie (m.in. MD Anderson, Stany Zjednoczone Ameryki). Wyniki analizy Qaly stanowią podstawę planowania rozmieszczenia środków finansowych w sektorze ochrony zdrowia. Określone wartości współczynnika Qaly, uzyskane w trakcie badania wybranej grupy chorych lub w danym ośrodku, rzutują na strukturę strategii finansowania placówek medycznych w przyszłych latach. Rozpowszechnione w Anglii, Francji, czy Stanach Zjednoczonych, badania wartości Qaly są w Polsce niemalże nieznane. Nieliczne i niedostępne w międzynarodowych bazach naukowych opracowania polskojęzyczne, poruszają zwykle kwestię metodologii i celów badania jakości życia chorych onkologicznie, rzadko popierając wysnute wnioski oryginalnymi danymi pochodzącymi z ankietyzacji [1].

\section{Dyskusja}

Wśród licznych formularzy służących ocenie HRQoL i Qaly [10], kwestionariusz EQ-5D-3L zajmuje szczególną pozycją jako najczęściej stosowany i jedyny rekomendowany przez NICE. Zgodnie z dostępną bazą piśmienniczą, w badaniach HRQoL, samoocena chorego onkologicznie z użyciem EQ-5D-3L, pozwala na wiarygodne obliczenie wskaźnika Qaly i ocenę efektywności klinicznej wybranego postępowania medycznego [3-6]. Zgromadzone w ten sposób dane pozwalają jednoznacznie wskazać całkowity zysk zdrowotny, płynący z diagnostyki i leczenia chorych onkologicznie, zapewniając jednocześnie możliwość porównania uzyskanych 
wyników z rezultatami badań prowadzonych w różnych krajach świata. Wskaźnik Qaly jest wielkością ważną tak dla chorego, jak i społeczności, w której żyje.

Baza piśmiennicza, traktująca o roli i metodologii badania wskaźnika Qaly jest jednakże ograniczona. Prawdopodobną przyczyną niewielkiej dostępności danych, jest pracochłonność prowadzenia podobnych analiz. Mnogość jednostek chorobowych oraz rosnąca zapadalność na nowotwory złośliwe na świecie, narzuca na jednostki ochrony zdrowia konieczność monitorowania coraz większej liczby chorych, wśród których dominują przypadki chorób trwających lub wznów nowotworowych. Badania HRQoL znajdują zastosowanie w odniesieniu do każdego etapu choroby, jednakże najbardziej wartościowa wydaje się być ankietyzacja prowadzona po upływie minimum 12 miesięcy od momentu ustalenia rozpoznania. Postępowanie takie pozwala nie tylko ocenić jakość życia chorych, ale także stanowi element monitorowania przeżywalności. Najbardziej korzystne z punktu widzenia założeń prezentowanych analiz, wydaje się być powtarzane okresowo badanie wybranym kwestionariuszem z częstotliwością jednej ewaluacji rocznie. Dotyczy to szczególnie grup chorych, leczonych metodami najistotniej rzutującymi na jakość życia (np. z włączeniem okaleczających zabiegów chirurgicznych). Z badania jakości życia warunkowanej zdrowiem nie wyłącza się osób leczonych paliatywnie, jednakże nie istnieją pozycje bibliograficzne, w których opisywana jest ta szczególna grupa chorych onkologicznie.

Pomimo powszechnego zrozumienia istoty prowadzenia badań nad wartością wskaźnika Qaly na świecie oraz istniejących regulacji prawnych w Polsce, badania HRQoL z uwzględnieniem zysku zdrowotnego Qaly nie są prowadzone.

\section{Wnioski}

Badanie współczynnika Qaly pozwala określić całkowity zysk zdrowotny, płynący z postępowania medycznego, realizowanego wobec chorych onkologicznie i jako takie, powinno być realizowane jako element standardowej praktyki klinicznej.

\section{Konflikt interesu / Conflict of interest}

Nie występuje / None

\section{Etyka / Ethics}

Treści przedstawione w artykule są zgodne z zasadami Deklaracji Helsińskiej, dyrektywami EU oraz ujednoliconymi wymaganiami dla czasopism biomedycznych.

\section{Piśmiennictwo / References}

[1] Turska W, Skowron A. Metodyka oceny jakości życia. Farm Pol 2009;65:572-80.

[2] Dostęp w Internecie: World Health Organization (WHO). Division of Mental Health and Prevention of Substance Abuse. (1997). WHOQOL : measuring quality of life. Dostęp w: https://apps.who.int/iris/ handle/10665/63482.

[3] Summerfield AQ, Barton GR. Sensitivity of EQ-5D-3L, HUI2, HUI3, and SF-6D to changes in speech reception and tinnitus associated with cochlear implantation. Qual Life Res 2019;28:1145-54.

[4] Van Hout B, Janssen MF, Feng YS, Kohlmann T, Busschbach J, et al. Interim scoring for the EQ-5D-5L: mapping the EQ-5D-5L to EQ-5D-3L value sets. Value Health 2012;15:708-15.

[5] Endarti D, Riewpaiboon A, Thavorncharoensap M, Praditsitthikorn N, Hutubessy R, et al. A Comparison of EQ-5D-3L Index Scores Using Malaysian, Singaporean, Thai, and UK Value Sets in Indonesian Cervical Cancer Patients. Value Health Reg Issues 2018;15:50-5.

[6] Dostęp w Internecie: EuroQol Research Foundation. UK English sample version of the EQ-5D-3L.The Netherlands: EuroQol Group EQ-5D, EuroQol; 2009. www.euroqol.org/eq-5d-instruments/sample- 
demo/). Data ostatniej aktualizacji: 18.12.2019.

[7] Dostęp w Internecie: Internetowy System Aktów Prawnych, Monitor Polski z dnia 31.10.2019 r. (M.P. z 2019 r., poz.1040). http://prawo.sejm.gov.pl/isap.nsf/DocDetails.xsp?id=WMP20190001040. Data ostatniej aktualizacji: 29.10.2019.

[8] Dostęp w Internecie: Agencja Oceny Technologii Medycznych i Taryfikacji, http://www.aotm.gov.pl/ www/komunikat-wys-progu/. Data ostatniej aktualizacji: 04.11.2019r.

[9] Dostęp w Internecie: Globocan 2018, Cancer Fact Sheets. Ferlay J, Ervik M, Lam F, Colombet M, Mery L, Piñeros M, Znaor A, Soerjomataram I, Bray F (2018). Global Cancer Observatory: Cancer Today. Lyon, France: International Agency for Research on Cancer. http://gco.iarc.fr/today/data/factsheets/ cancers/23-Cervix-uteri-fact-sheet.pdf. Data ostatniej aktualizacji: 01.12.2019.

[10] Konkol M, Galuba A, Milecki P. Jakość życia chorych w trakcie leczenia radioterapią SBRT na aparacie CyberKnife z powodu raka prostaty. Letters in Oncology Science 2017;14:55-60. 